\title{
Association Assessment among Risk Factors and Breast Cancer in a Low Income Country: Bangladesh
}

\author{
Kawsar Ahmed ${ }^{1 *}$, Sayed Asaduzzaman ${ }^{1}$, Mamun Ibn Bashar $^{2}$, Goljar Hossain $^{2}$, \\ Touhid Bhuiyan ${ }^{3}$
}

\begin{abstract}
Background: In the low incoming country Bangladesh, breast cancer is second most common neoplasm and is increasing at an alarming rate among females. Lack of awareness and illiteracy are contributory factors for late presentation and therefore mortality. Purpose: To examine associations of different factors with breast cancer mortality and to raise awareness among the women of society in Bangladesh. Materials and Methods: This descriptive case-control study was conducted on 160 participants from April 2011 till July 2014. Through a valid questionnaire covering personal and family history, data were collected by face to face interview. For analyzing correlations among factors with breast cancer data, binary logistic regression, Pearson's $\chi 2$ - value, odd ratios and p-value tests were conducted with SPSS version 20. Results: The mean age of the patients was 43.0 $(\mathrm{SD}= \pm 11.12)$. In ascending order the leading significant factors were hormone therapy $(\mathrm{p}<0.0000,0 \mathrm{R}=4.897)$, abortion $(p<0.0001, O R=3.452)$, early start menarche $(p<0.0002, O R=3.500)$, family history $(p<0.0022, O R=3.235)$, and late menopause $(p<0.0093, O R=3.674)$ with both $\chi 2$ test and logistic regression analyses. Non-significant factors were cancer experience, fatty food habits, marital status and taking alcohol. Conclusions: Regarding the investigation of this study, significant and insignificant factor's correlation visualization with breast cancer will be helpful to increase awareness among Bangladeshi women as well as all over the world.
\end{abstract}

Keywords: Bangladesh - breast cancer - correlation - data mining - risk factors - regression

Asian Pac J Cancer Prev, 16 (17), 7507-7512

\section{Introduction}

Cancer is deathful disease and caused by uncontrolled cell growth. The initial affected cell types and their positions mainly have classified the cancer types. In South Asia like India, Bangladesh, Nepal, Myanmar, Pakistan, and Tibet etc. 76,000 women die of breast cancer in a year (Ahmed et al., 2013). Although there is no national cancer registry in Bangladesh but it is estimated that 30,000 women are died for breast cancer. Incidence and Mortality in Bangladesh of Breast Cancer people are increasing at alarming rate and already reach an unexpected level. It is holding 2nd position in the world among 100 different types of cancer. Bangladesh stays at top rank for breast cancer in South Asian countries (Ginsburg, 2013). The report of World Health Organization (WHO) is also published that the death rate of breast cancer in Bangladesh is high and ranked in $2^{\text {nd }}$ position all over the world. Approximately $60 \%$ of women are illiterate and $27 \%$ of the population is undernourished of low incoming country, Bangladesh. In Bangladesh 3,300 people in urban areas are served by one doctor and more than 15,000 people in rural areas. It creates a burning question about general population health in Bangladesh.

Poor health service in Bangladesh can't touch the dream of modern medical invention. Although new technologies are developing day by day to reduce the number of breast cancer people. But perspectives to Bangladesh new technologies are not good enough to reduce breast cancer people. Because most of the women are illiterate and suffered from husband as well as society and have given low priority. They also believe that an evil spirit is responsible to occurring breast cancer and punishment for bad deeds. Both illiterate and educated women have insufficient knowledge about breast cancer. This problem is not only for Bangladesh but also other countries (Morse et al., 2014; Altay et al., 2015; Liu et al., 2015). So it's needed to increase the doctors and awareness among all population both rural and urban areas in Bangladesh. The awareness can be increased to provide the proper knowledge about factors those are associated with breast cancer.

\footnotetext{
${ }^{I}$ Department of Information and Communication Technology, ${ }^{2}$ Department of Statistics, Mawlana Bhashani Science and Technology University, Tangail, ${ }^{3}$ Department of Software Engineering, Daffodil International University, Dhaka, Baangladesh *For correspondence: kawsar_it08050@yahoo.com
} 
Like as population health service, socioeconomic status is not good well in Bangladesh. The research articles (Mohaghegh et al., 2014; Kye et al., 2015; Ozkaraman et al., 2015) in different countries proposed that socioeconomic status factor has a vigorous relationship with breast cancer. Like as further cancers breast cancer also depends on some other factors like age, lifestyle, family history and health conditions etc. (Gathani et al., 2014). But every factor has not equaled responsibility to increasing breast cancer. The papers (White et al., 2014; Wilson, 2014; Bilinski, 2015) have proposed that the risk of cancer increases with age growing. But midlife people stay at danger zone. The young people and BMI factors have little bit risk to developing breast cancer (Kruk, 2015; Wright, 2015). Pregnancy (Britt et al., 2007) and breast feeding (Mohaghegh et al., 2015) have also association to develop breast cancer. The chance of breast cancer could be reduced up to three times by Pregnancy and delivering (Akbari et al., 2012). Abnormal menstruation time also implies from at front to increase or create breast cancer. Menarche starts early before 12 years and Menopause stops at late after 55 years are mostly responsible to increase breast cancer patients (Ahmed, 2013; Shankar, 2015; Veisy, 2015).

Abortion is another significant factor to raising breast cancer people (Mohaghegh et al., 2015). Family history (Kye et al., 2015), therapy at chest area (Ahmadloo et al., 2013; Tinari et al., 2015; Yu et al., 2015), are another significant factors for breast cancer mortality. Cancer of parents has higher priority to develop cancer for next generation than cancer of grandparents not only for breast cancer but also other cancers (Ahmed K, 2013). Regular physical exercise can also reduce the probability to occurring breast cancer (Altay et al., 2015). But marital status and cancer experience (Wilson, 2014) are not good enough associated with breast cancer. Depression is sufficiently correlated with breast cancer risk development (Sun et al., 2015; Tabrizi et al., 2015).

Now by analyzing the different factors status the risk level of breast cancer can be easily detected. This detection is helpful for proper cancer treatment. Because completely remove or destroy of cancer is less possible for late detection. Most breast cancers can be cured if it is found and treated at early stage. In our previous study (Ahmed, 2013) we developed a breast cancer detection system. Where we tried to prove a moral sentence, "Prevention is better than cure". But in previous the impact of factors on breast cancer was not briefly described and data was one half compare to this study.

This research examined the impact of different factors on breast cancer. From the background study we come to know that the factors association with breast cancer varied from region to region, country to country. But there is lack of proper information about Bangladeshi breast cancer women. So this study is also designed to assess correlation among breast cancer factors perspective to Bangladeshi women.

\section{Materials and Methods}

Data of 160 persons (women) is collected from different diagnostic center and medical college hospital. Both the patients and non-patients data had been included where all the participants were women whose ages were about 25 to 75 . The whole data collection process was performed based on a questioner which was prepared using some former study on breast cancer and some common criteria's related to breast cancer. About 20 risk factors were considered for Breast cancer assessment in Bangladeshi population, which includes age, gender, hereditary, previous health examination, use of antihypersensitive drugs, food habit, obesity, environment, excessive alcohol, late Menopause, early Menarche, hormone therapy, abortion, exercise, depression, marital status, genetic risk, outdoor activities and affected any cancer before based on the previous studies. The collected data was approved by Dr. Rasel Ahmed, Salimullah Medical College and Hospital, Dhaka, Bangladesh.

\section{Data pre-processing of obtained data}

Data is incomplete, inconsistent and noisy in the existent-world. Raw data is highly susceptible to noise, missing values and inconsistency that may affect the data analysis results. Data transformations, data integration, data reduction, data discretization, data cleaning are the major tasks of the data pre-processing as it is one of the most decisive steps of data analysis technique that involves metamorphosing raw data into a perceivable format. The levelling of missing values, detection of the conflict data and blend those data and so on of the process which has been met.

Reduction of memory and normalizing of the values used to representation of information from database occurs by data pre-processing. Future classification and statistical analysis has been taking place at the Statistical analysis of the pre-processed data section and result section those which are associated and those which are not associated. Non associated factors with breast cancer were discarded from raw data.

Statistical analysis of the pre-processed data:

The main goal of this study is to discover the association among the factors with breast cancer and detect those factors which are statistically significant. Firstly, after pre-processing the collected data, association and $p$-value among breast cancer with various factors has been encountered by $\chi 2$ - test. Among those factors which are statistically significant $(\mathrm{p}<0.05)$, the odds ratio (OR) and $95 \%$ confidence interval (C.I) has been detected by binary logistic regression. After that, the Pearson $\chi 2$ - test has been used to determine the association among factors. The whole analysis has been executed by IBM Statistical Package for Social Sciences (SPSS version 20.0).

\section{Results}

The data of 160 women of Bangladesh (where half of them were affected by breast cancer and the rest of them were not affected) analysed in the result section. Here the total analysis process take place at the three different tables includes frequency distribution with p-value, odds 
Association Assessment among Risk Factors and Breast Cancer in a Low Income Country: Bangladesh

Table 1. Frequency Distribution with p-value of Risk Factors Between Case Group and Control Group

\begin{tabular}{|c|c|c|c|}
\hline \multirow{2}{*}{ Factors } & \multicolumn{2}{|c|}{ Cancer status } & \multirow{2}{*}{ P-value } \\
\hline & $\begin{array}{c}\text { Affected } \\
\mathrm{n}(\%)\end{array}$ & $\begin{array}{c}\text { Unaffected } \\
\mathrm{n}(\%)\end{array}$ & \\
\hline \multicolumn{4}{|l|}{ Age } \\
\hline Below 30 & $3(3.8)$ & $4(5)$ & \multirow{3}{*}{0.4572} \\
\hline $30-50$ & $51(63.8)$ & $57(71.2)$ & \\
\hline Above 50 & $26(32.5)$ & $19(23.8)$ & \\
\hline \multicolumn{4}{|c|}{ Family affected Member } \\
\hline No & $30(37.50)$ & $51(63.8)$ & \multirow{3}{*}{$0.0022^{*}$} \\
\hline Parent & $34(42.50)$ & $16(20.0)$ & \\
\hline Grand parent & $16(20)$ & $13(16.2)$ & \\
\hline \multicolumn{4}{|l|}{ Married } \\
\hline No & $32(40)$ & $22(27.50)$ & \multirow[t]{2}{*}{0.0945} \\
\hline Yes & $48(60)$ & $58(72.5)$ & \\
\hline \multicolumn{4}{|c|}{ Menarche Start Early } \\
\hline No & $34(42.50)$ & $57(71.2)$ & \multirow[t]{2}{*}{$0.0002 *$} \\
\hline Yes & $46(57.5)$ & $23(28.8)$ & \\
\hline \multicolumn{4}{|c|}{ Menopause Stop Late } \\
\hline No & $58(72.5)$ & $71(88.8)$ & \multirow[t]{2}{*}{$0.0093 *$} \\
\hline Yes & $22(27.5)$ & $9(11.2)$ & \\
\hline \multicolumn{4}{|l|}{ Regular Exercise } \\
\hline Not Everyday & $46(57.5)$ & $31(38.8)$ & \multirow[t]{2}{*}{$0.0176^{*}$} \\
\hline Everyday & $34(42.5)$ & $49(61.2)$ & \\
\hline \multicolumn{4}{|l|}{ Fatty Food Habits } \\
\hline No & $54(67.5)$ & $57(71.2)$ & \multirow[t]{2}{*}{0.6069} \\
\hline Yes & $26(32.5)$ & $23(28.8)$ & \\
\hline \multicolumn{4}{|l|}{ BMI } \\
\hline Below 23 & $26(32.5)$ & $18(22.5)$ & \multirow[t]{3}{*}{$.0291 *$} \\
\hline 24-27 & $42(52.5)$ & $36(45)$ & \\
\hline Above 27 & $12(15)$ & $26(32.5)$ & \\
\hline \multicolumn{4}{|c|}{ Hormone therapy taken yet } \\
\hline No & $30(37.5)$ & $56(70.0)$ & \multirow[t]{2}{*}{$0.0000 *$} \\
\hline Yes & $50(62.5)$ & $24(30)$ & \\
\hline \multicolumn{4}{|c|}{ Before had any cancer } \\
\hline No & $58(72.5)$ & $65(81.2)$ & \multirow[t]{2}{*}{0.1893} \\
\hline Yes & $22(27.50)$ & $15(18.8)$ & \\
\hline \multicolumn{4}{|l|}{ Abortion } \\
\hline No & $50(62.5)$ & $71(88.8)$ & \multirow[t]{2}{*}{$0.0001 *$} \\
\hline Yes & $30(37.5)$ & $9(11.2)$ & \\
\hline \multicolumn{4}{|l|}{ Take alcohol } \\
\hline No & $52(65)$ & $48(68)$ & \multirow[t]{2}{*}{0.5136} \\
\hline Yes & $28(35)$ & $32(40)$ & \\
\hline
\end{tabular}

ratio with confidence interval of predictors and association among factors.

Table 1. represents the frequency distribution of cancer patients (case group) and control group with significant variation among risk factors of breast cancer. Here it clearly shows that the factor "hormone therapy taken" ( $p<0.0000)$ is highly associated with breast cancer and "Abortion" $(\mathrm{p}<0.0001)$, "menarche start early" $(\mathrm{p}<0.0002)$, "regular exercise" $(\mathrm{p}<0.0176)$, "family member affected" ( $<<0.0022)$, "menopause stop late" $(\mathrm{p}<0.0093)$, "BMI" ( $\mathrm{p}<0.0291)$, are also highly associated with breast cancer perspective to Bangladeshi women.

The net effects of predictors (risk factors) on breast cancer of Bangladeshi people have been illustrated in the Table 2. Odds ratio (OR) has been used to compare different groups with $95 \%$ confidence interval (CI) is also presented in Table 2 . Here from the table it is clearly depicts that "family member affected", "Menarche start early", "Menopause stop late", "BMI", "Hormone therapy taken", "take abortion" have statistically significant relationships $(\mathrm{p}<0.05)$ with breast cancer of Bangladeshi people.

"Hormone therapy taken" is a highly significant factor for breast cancer especially for women who had ever been taken any hormone therapy have 4.897 times higher risk than those who did not take any hormone therapy. Similarly except the factor "Take regular exercise", "Menarche start early, Menopause stop late, BMI (Above 28), Family member affected (parent affected), Take abortion " are respectively 3.500, 3.674, 0.192, 3.235, 3.452 times higher than those who are not related with those factors.

The net effects of predictors (risk factors) on breast cancer of Bangladeshi people have been illustrated in the Table 2. Odds ratio (OR) has been used to compare different groups with $95 \%$ confidence interval (CI) is also presented in Table 2 . Here from the table it is clearly depicts that "family member affected", "Menarche start early", "Menopause stop late", "BMI", "Hormone therapy taken", "take abortion" have statistically significant relationships $(\mathrm{p}<0.05)$ with breast cancer of Bangladeshi people.

Table 2. Odds Ratio with Confidence Interval of Predictors

\begin{tabular}{|c|c|c|c|c|c|c|}
\hline \multirow[t]{2}{*}{ Predictors } & \multirow[t]{2}{*}{ Category } & \multirow[t]{2}{*}{ B } & \multirow[t]{2}{*}{ Sig. } & \multirow[t]{2}{*}{ Odds ratio } & \multicolumn{2}{|c|}{ 95\% C.I. for odds ratio } \\
\hline & & & & & Lower & Upper \\
\hline \multirow[t]{3}{*}{ Family member affected } & No (Ref) & & 0.04 & & & \\
\hline & Parent & 1.174 & 0.014 & 3.235 & 1.264 & 8.282 \\
\hline & Grandparent & 0.766 & 0.155 & 2.152 & 0.749 & 6.184 \\
\hline \multirow[t]{2}{*}{ Menarche start early } & No (Ref) & 1.253 & 0.002 & 3.5 & 1.56 & 7.851 \\
\hline & Yes & & & & & \\
\hline \multirow[t]{2}{*}{ Menopause stop late } & No (Ref) & 1.301 & 0.016 & 3.674 & 1.269 & 10.639 \\
\hline & Yes & & & & & \\
\hline \multirow[t]{2}{*}{ Take regular exercise } & Not-everyday (Ref) & & & & & \\
\hline & Everyday & -0.464 & 0.26 & 0.629 & 0.281 & 1.41 \\
\hline \multirow[t]{3}{*}{ BMI } & Below 24 (Ref) & & 0.012 & & & \\
\hline & $24-28$ & -0.184 & 0.694 & 0.832 & 0.334 & 2.076 \\
\hline & Above 28 & -1.651 & 0.006 & 0.192 & 0.059 & 0.622 \\
\hline \multirow[t]{2}{*}{ Hormone therapy taken } & No (Ref) & & & & & \\
\hline & Yes & 1.589 & 0 & 4.897 & 2.104 & 11.397 \\
\hline \multirow[t]{2}{*}{ Take abortion } & No (Ref) & & & & & \\
\hline & Yes & 1.239 & 0.015 & 3.452 & 1.277 & 9.33 \\
\hline
\end{tabular}


Table 3. Associations among Factors of Breast Cancer Data

\begin{tabular}{|c|c|c|c|c|c|c|c|c|c|c|c|c|}
\hline & & $\begin{array}{l}\text { Family } \\
\text { Member } \\
\text { Affected }\end{array}$ & $\begin{array}{c}\text { Marital } \\
\text { Status }\end{array}$ & $\begin{array}{c}\text { Menarche } \\
\text { Start } \\
\text { Early }\end{array}$ & $\begin{array}{c}\text { Menopause } \\
\text { Stop } \\
\text { Late }\end{array}$ & $\begin{array}{l}\text { e Take } \\
\text { Regular } \\
\text { Exercise }\end{array}$ & $\begin{array}{l}\text { Fatty } \\
\text { Food } \\
\text { Habit }\end{array}$ & BMI & $\begin{array}{l}\text { Hormone } \\
\text { therapy }\end{array}$ & $\begin{array}{c}\text { Cancer } \\
\text { Experience }\end{array}$ & $\begin{array}{c}\text { Take } \\
\text { Abortion }\end{array}$ & $\begin{array}{c}\text { Take } \\
\text { Alcohol }\end{array}$ \\
\hline \multirow[t]{2}{*}{ Age } & $\chi^{2}$ & 0.867 & $9.016^{*}$ & 0.686 & $46.395 * *$ & $9.073 *$ & 0.862 & 8.674 & 1.198 & 1.508 & 3.452 & $18.878 * *$ \\
\hline & $\mathrm{p}$ & 0.929 & 0.011 & 0.709 & 0 & 0.011 & 0.650 & 0.07 & 0.549 & 0.47 & 0.178 & 0 \\
\hline \multicolumn{13}{|c|}{ Family Member Affected } \\
\hline & $x^{2}$ & & 2.316 & 1.432 & 1.301 & $6.815^{*}$ & 0.25 & 2.622 & $8.594 *$ & 0.802 & 4.885 & 5.84 \\
\hline & $\mathrm{p}$ & & 0.314 & 0.489 & 0.522 & 0.033 & 0.882 & 0.623 & 0.014 & 0.67 & 0.087 & 0.054 \\
\hline \multicolumn{13}{|c|}{ Marital Status } \\
\hline & $\chi^{2}$ & & & 0.839 & 0.052 & 0 & 2.709 & 0.783 & 2.839 & 0.348 & 1.517 & 1.677 \\
\hline & $\mathrm{p}$ & & & 0.36 & 0.82 & 0.997 & 0.100 & 0.676 & 0.097 & 0.555 & 0.218 & 0.195 \\
\hline \multicolumn{13}{|c|}{ Menarche Start Early } \\
\hline & $x^{2}$ & & & & 0.434 & 3.426 & $.987 *$ & 0.304 & 0.121 & 0.131 & $5.282 *$ & 0.382 \\
\hline & $\mathrm{p}$ & & & & 0.51 & 0.064 & 0.023 & 0.859 & 0.728 & 0.717 & 0.002 & 0.536 \\
\hline \multicolumn{13}{|c|}{ Menopause Stop Late } \\
\hline & $x^{2}$ & & & & & $10.466 * *$ & 0.427 & 0.645 & 0.018 & 0.006 & 0.043 & $5.401 *$ \\
\hline & $\mathrm{p}$ & & & & & 0.001 & 0.513 & 0.724 & 0.892 & 0.936 & 0.836 & 0.02 \\
\hline \multicolumn{13}{|c|}{ Regular Exercise } \\
\hline & $\chi^{2}$ & & & & & & 0.295 & 1.283 & 0.194 & 0.201 & 2.432 & 2.539 \\
\hline & $\mathrm{p}$ & & & & & & 0.587 & 0.527 & 0.66 & 0.654 & 0.119 & 0.111 \\
\hline \multicolumn{13}{|c|}{ Fatty Food Habits } \\
\hline & $\chi^{2}$ & & & & & & & 1.876 & -0.127 & 1.179 & 0.033 & 0.539 \\
\hline & $\mathrm{p}$ & & & & & & & 0.391 & 0.11 & 0.278 & 0.675 & 0.539 \\
\hline \multirow[t]{2}{*}{ BMI } & $x^{2}$ & & & & & & & & 2.761 & 5.177 & 2.15 & 3.534 \\
\hline & $\mathrm{p}$ & & & & & & & & 0.251 & 0.075 & 0.341 & 0.171 \\
\hline \multicolumn{13}{|c|}{ Hormone Therapy } \\
\hline & $\chi^{2}$ & & & & & & & & & 0.175 & 2.142 & 0.543 \\
\hline & $\mathrm{p}$ & & & & & & & & & 0.676 & 0.143 & 0.461 \\
\hline \multicolumn{13}{|c|}{ Cancer Experience } \\
\hline & $\chi^{2}$ & & & & & & & & & & 1.738 & 3.565 \\
\hline & $\mathrm{p}$ & & & & & & & & & & 0.187 & 0.059 \\
\hline \multicolumn{13}{|c|}{ Take Abortion } \\
\hline & $x^{2}$ & & & & & & & & & & & 0.997 \\
\hline & $\mathrm{p}$ & & & & & & & & & & & 0.318 \\
\hline
\end{tabular}

** Highly sinificant association among factors * Sinificant association among factors

"Hormone therapy taken" is a highly significant factor for breast cancer especially for women who had ever been taken any hormone therapy have 4.897 times higher risk than those who did not take any hormone therapy. Similarly except the factor "Take regular exercise", "Menarche start early, Menopause stop late, BMI (Above 28), Family member affected (parent affected), Take abortion " are respectively 3.500, 3.674, 0.192, 3.235, 3.452 times higher than those who are not related with those factors.

Table 3. Illustrate that the Pearson's $\chi 2$ with p-value among factors. Here it is assumed that those associations among factors are highly significant whose $\mathrm{p}$-value is less than $0.01(<1 \%)$ and those are significant whose $\mathrm{p}$-value is less than $0.05(<5 \%)$. From the table there are highly significant relationship between "Menopause stop late- Age of the correspondent $(\mathrm{p}=.000, \chi 2=46.395)$ ", "Menopause stop late - Take regular exercise $(\mathrm{p}=.001$, $\chi 2=10.466$ )" and "Age of the correspondent- take alcohol $(\mathrm{p}=.000, \chi 2=18.878)$ ". There is also significant relationship between "family member affected - take regular exercise $(\mathrm{p}=.033, \chi 2=6.815)$ ", "family member affected -hormone therapy taken $(\mathrm{p}=.014, \chi 2=8.594)$ ", "Menarche start earlyFatty food habits $(\mathrm{p}=.023, \chi 2=.987)$ ", "Menarche start early- Take abortion $(\mathrm{p}=.002, \chi 2=5.282)$ ", "Menopause stop late-Take alcohol $(\mathrm{p}=.020, \chi 2=5.401)$.

\section{Discussion}

The study has been performed over 160 women including 80 patients and 80 insensible women where the mean age of participants was 44.05 years, SD $( \pm 11.22)$ in Bangladesh. The same findings are visible in different studies (Love, 2012; Ahmed, 2013; Tazhibi et al., 2014). Our study has explored that "Hormone therapy" is the leading factor for breast cancer. It is also notable that the women who ever taken any hormone therapy have more prone to affect by breast cancer than their counterparts. The same result was proposed by Love R. (2012) leading the survey over Bangladeshi women. Likewise, the same case was found in different researches of different countries (Ahmadloo et al., 2013; Tinari et al., 2015; Yu et al., 2015). In our investigation family history factor is highly associated with breast cancer which was also found as a significant risk factor by Gathani et al. (2014). Especially the mother affected by breast cancer is considerably more responsible about three times higher than other family members. Like different world wide studies (Shankar, 2015; Veisy, 2015) this study has been noticed that the factors "Menarche start early", "Menopause stop late" are another two significant factors for Breast cancer. From our analysis it is found that women whose menarche is started early have more high risk $(\mathrm{OR}=3.500)$ than late 
started women. The women whose menopause stop at late have vigorous risk $(\mathrm{OR}=3.674)$ compare to early stopped women. Beside these we have ascertained another risk factor "Abortion" that is highly associated with our object perspective to Bangladesh. The probability of invading breast cancer is three times higher for those who are taking abortion compare to not taking women. The above mentioned five factors are found significant both in $\chi 2$ test and binary logistic regression analysis. It has been explored two factors in our study which are insignificant in binary logistic regression but significant in chi square test. Those factors are Regular Physical Exercise $(\mathrm{p}<0.0176)$ and BMI $(p<0.0291)$. One the other hand, marital status does not act as a responsible factor for breast cancer. The same result was also shown by Mohaghegh et al. (2015). In our study fatty food habits, taking alcohol, before cancer experience have not appeared as a major factor for breast cancer perspective to Bangladeshi women. Limitations: Here the entire statistical data analysis was processed using 160 data containing both patients and non-patients information. But for large amount of data the results of the statistical analysis may petty dissent from the actual result of this study. Besides, this analysis was done on only Bangladeshi women which is not good enough for the most probably effective and precise result.

In conclusion, as Bangladesh is a low incoming and conservative country, most of the women are not aware of deathful breast cancer disease because of lacking education. Besides, a vast number of hearsay cramps the society nastily, women conceive disgrace of discuss on breast cancer with others. The researchers had worked on breast cancer and different tools and techniques has been updated day-by-day. In the paper the associative relation of factors has been detected with breast cancer and the possibility of preferences among the obtained factors has been estimated. The results can be used to increase awareness among women about different factors. It will be helpful for early prevention and better than cure. Moreover the research would depict to future researchers to find out some new era in the meantime to save the women from this atrocious curse. Otherwise one day the victims would by us or any relatives or anyone of the society.

\section{Acknowledgements}

The authors are grateful to all of the subjects who participated in this research.

\section{References}

Ahmadloo N, Kani AA, Mohammadianpanah M, et al (2013). Treatment outcome and prognostic factors of adult glioblastoma multiforme. J Egyptian National Cancer Institute, 25, 21-30.

Ahmed K, Emran AA, Tasnuba J, et al (2013). Early detection of lung cancer risk using data mining. Asian Pac J Cancer Prev, 14, 595-8.

Ahmed K, Habib MA, Jesmin T, et al (2013). Prediction of breast cancer risk level with risk factors in perspective to bangladeshi women using data Mining. International $J$ Computer Applications, 82, 36-41.

Akbari A, Hadi A, Tabib AA, et al (2012). Breast cancer risk reduction by parity and breastfeeding, islamic perspective; a case control study. Iran J Cancer Prev, 3, 56-61.

Altay B, Avci IA, Rizalar S, et al (2015). Breast and cervical cancer knowledge and awareness among university students. Asian Pac J Cancer Prev, 16, 1719-24.

Bilinski K, Byth K, Boyages J (2015). Association between latitude and breast cancer incidence in mainland Australian women", J Cancer Res, 2014, 1-9.

Britt K, Ashworth A, Smalley M (2007). Pregnancy and the risk of breast cancer. Endocrine-Related Cancer, 14, 907-933.

Chlebowski RT, Kuller LH, Prentice RL, et al (2009). Breast cancer after use of estrogen plus progestin in postmenopausal women. New England J Med, 360, 573-87.

Collaborative GHFBC (2012). Menarche, menopause, and breast cancer risk: individual participant meta-analysis, including 118964 women with breast cancer from 117 epidemiological studies. The lancet oncology, 13, 1141-51.

Gathani T, Ali R, Balkwill A, et al (2014). Ethnic differences in breast cancer incidence in England are due to differences in known risk factors for the disease: prospective study. British J Cancer, 11, 224-9.

Ginsburg OM (2013). Breast and cervical cancer control in low and middle-income countries: Human rights meet sound health policy. J Cancer Policy, 1, 35-41.

Kruk J (2015). "Overweight, Obesity, Oxidative stress and the risk of breast cancer". Asian Pac J Cancer Prev, 15, 9579-86.

Kye SY, Park EY, Oh K, et al (2014). Perceptions of cancer risk and cause of cancer risk in Korean adults. Cancer Research and Treatment, 47, 158-65.

Love R (2006). Hope for Breast Cancer in Bangladesh.

Liu MX, Li J, Geng YL, et al (2015). Correlation study of knowledge and behavior regarding breast care among female undergraduate students in China. Asian Pac J Cancer Prev, 15, 10943-7.

Mohaghegh P, Yavari P, Akbari M, et al (2015). Relationships between family levels of socioeconomic status and distribution of breast cancer risk factors. Iran J Cancer Prev, 8, 53-9.

Mohaghegh P, Yavari P, Akbari M, et al (2014). The correlation between the family levels of socioeconomic status and stage at diagnosis of breast cancer. Iran J Cancer Prev, 7, 232-8.

Montazeri AM, Ebrahimi N, Mehrdad, et al (2003). Delayed presentation in breast cancer: a study in Iranian women," $B M C$ women's health, 3, 1-4.

Morse EP, Maegga B, Joseph G, et al (2014). Breast cancer knowledge, beliefs, and screening practices among women seeking care at district hospitals in dar es salaam, Tanzania. Breast Cancer: Basic and Clinical Research, 8, 73-9.

Ozkaraman A, Culha I, Fadıloglu ZC, et al (2015). Relationships between social support and social image concerns in turkish women with breast cancer. Asian Pac J Cancer Prev, 16, 1795-802.

Shankar A, Rath GK, Roy S, et al (2015). Level of awareness of cervical and breast cancer risk factors and safe practices among college teachers of different states in India: do awareness programmes have an impact on adoption of safe practices? Asian Pac J Cancer Prev, 16, 927-932.

Society CC (2011). Breast cancer understanding your diagnosis.

Sun HL, Dong XX, Cong YJ, et al (2015). Depression and the risk of breast cancer: a meta-analysis of cohort studies. Asian Pac J Cancer Prev, 16, 3233-9.

Tabrizi FM (2015). Health promoting behavior and its influencing factors in Iranian breast cancer survivors. Asian Pac J Cancer Prev, 16, 1729-36.

Tazhibi M, Dehkordi ZF, Babazadez S, et al (2014). Investigation of the age trends in patients with breast cancer and different sizes of tumors in breast cancer research center of Isfahan 


\section{Kawsar Ahmed et al}

university of medical sciences in 2001-2010. J Education and Health Promotion, 3, 1-10.

Tinari N, Fanizza C, Romero M, et al (2015). Identification of subgroups of early breast cancer patients at high risk of nonadherence to adjuvant hormone therapy: results of an Italian Survey. Clinical Breast Cancer, 15, 131-7.

Veisy A, Lotfinejad S, Salehi K, et al (2015). Risk of breast cancer in relation to reproductive factors in north-west of Iran, 2013-2014. Asian Pac J Cancer Prev, 16, 451-5.

White MC, Holman DM, Boehm JE, et al (2014). Age and cancer risk. American Journal of Preventive Medicine, 46, 7-15.

Wilson FA, Wang Y, Stimpson JP(2014). The role of sick leave in increasing breast cancer screening among female employees in the U.S. Journal of Cancer Policy, 2, 89-92.

Wright CE, Harvie M, Howell A, et al (2015). Beliefs about weight and breast cancer: an interview study with high risk women following a 12 month weight loss intervention. Hereditary Cancer in Clinical Practice, 13, 1-9.

Yu JL, Choi DH, Huh SJ, et al (2015). Proportion and clinical outcomes of postoperative radiotherapy omission after breast-conserving surgery in women with breast cancer. Journal Breast Cancer, 18, 50-56. 